\title{
Cardiometabolic risk in adolescents students of high school: influence of work
}

\author{
Risco cardiometabólico em adolescentes estudantes do ensino médio: influência do trabalho \\ Riesgo cardiometabólico en adolescentes estudiantes de la enseñanza medio: influencia del trabajo
}

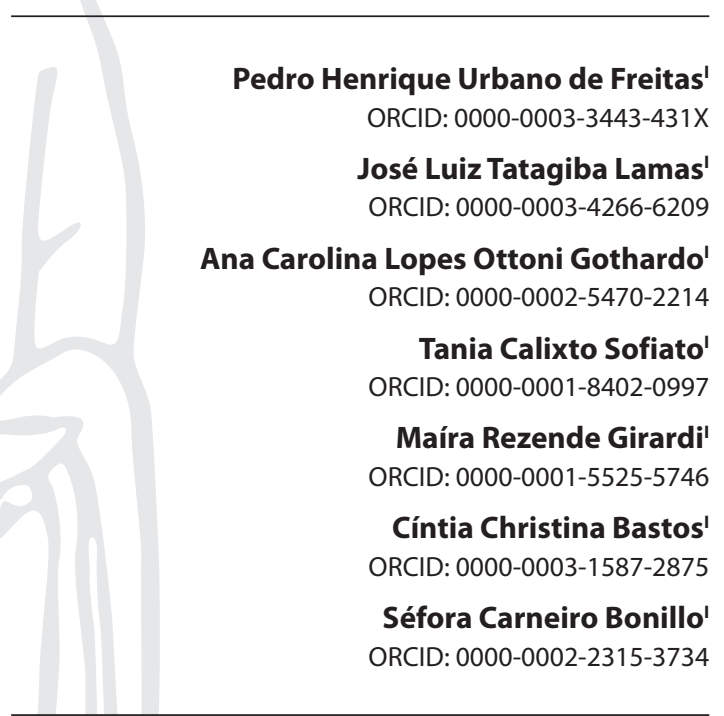

'Universidade Estadual de Campinas. Campinas, São Paulo, Brazil.

How to cite this article: Freitas PHU, Lamas JLT, Gothardo ACLO, Sofiato TC, Girardi MR, Bastos CC, et al. Cardiometabolic risk in adolescents students of high school: influence of work.

Rev Bras Enferm. 2020;73(Suppl 4):e20190041. doi: http://dx.doi.org/10.1590/0034-7167-2019-0041

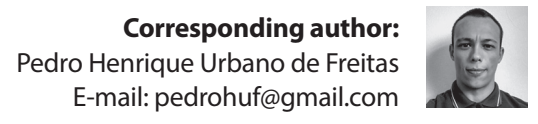

EDITOR IN CHIEF: Antonio José de Almeida Filho ASSOCIATE EDITOR: Hugo Fernandes

Submission: 01-22-2019 Approval: 09-15-2019

\begin{abstract}
Objectives: to evaluate and compare the prevalence of cardiometabolic risk factors among high school adolescents with or without jobs, and to establish an association between risk factors and changes in lifestyle after starting to work. Methods: quantitative cross-sectional study. An instrument was applied to assess socio-demographic characteristics and habits. Dietary pattern was assessed by the Brazilian Healthy Eating Index. Nutritional status was assessed by the Z-score. Data were submitted to statistical analysis and comparison between groups and periods, as well as association and correlation was done. Results: the prevalence of high blood pressure was 7.7\%. High BP affected $4.5 \%$ of non-workers and $10.9 \%$ of workers. Dietary patterns were inappropriate and $51.2 \%$ did not engage in physical activity. The prevalence of obesity was $28.3 \%$. The results showed an association between work and alcohol consumption, lack of physical activity and reduced sleep quality. Conclusions: work increased exposure to certain cardiometabolic risk factors. Descriptors: Adolescent; Students; Work; Hypertension; Nursing.
\end{abstract}

\section{RESUMO}

Objetivos: avaliar e comparar a prevalência de fatores de risco cardiometabólico entre adolescentes e estabelecer associação entre os fatores de risco e mudança de hábitos após início do trabalho. Métodos: estudo transversal quantitativo. Foi aplicado um instrumento para conhecer as características sociodemográficas e hábitos. O padrão alimentar foi avaliado por meio do Índice de Qualidade da Dieta Revisado para população brasileira e o estado nutricional pelo escore Z. Os dados foram submetidos à análise estatística de comparação entre grupos e tempo, associação e correlação. Resultados: a prevalência de pressão arterial elevada foi de 7,7\%. Dentre estes 4,5\% não trabalhavam e 10,9\% eram trabalhadores. Padrões alimentares se mostraram inapropriados e $51,2 \%$ não praticavam atividade física. A prevalência de obesidade foi de $28,3 \%$. Foi observado associação entre trabalho e consumo de álcool, redução de atividade física e qualidade de sono. Conclusões: o trabalho aumentou a exposição a determinados fatores de risco cardiometabólico.

Descritores: Adolescente; Estudantes; Trabalho; Hipertensão; Enfermagem.

\section{RESUMEN}

Objetivos: evaluar y comparar la prevalencia de factores de riesgo cardiometabólicos entre adolescentes y establecer una asociación entre los factores de riesgo y el cambio de hábitos después de empezar a trabajar. Métodos: se trata de un estudio cuantitativo transversal. Se aplicó un instrumento para conocer las características y los hábitos sociodemográficos. El patrón alimenticio se evaluó mediante el Índice de Calidad de la Dieta Revisado para la población brasileña y el estado nutricional, por la puntuación Z. Los datos se sometieron a un análisis estadístico de comparación entre grupos y tiempo, asociación y correlación. Resultados: la prevalencia de la hipertensión arterial era del 7,7\%. De ellos, el $4,5 \%$ no trabajaba y el 10,9\% estaba empleado. Los patrones de alimentación eran inapropiados y el $51,2 \%$ no practicaba actividad física. La prevalencia de la obesidad era del $28,3 \%$. Se observó una asociación entre el trabajo y el consumo de alcohol, la reducción de actividad física y la calidad del sueño. Conclusiones: el trabajo ha aumentado la exposición a determinados factores de riesgo cardiometabólicos.

Descriptores: Adolescentes; Estudiantes; Trabajo; Hipertensión; Enfermería. 


\section{INTRODUCTION}

Cardiovascular risk among adult individuals has been well documented in longitudinal and experimental studies ${ }^{(1-2)}$. However, in recent decades, studies have been investigating the habits of the adolescent population, considering that adolescence is the phase in which individuals have initial contact with risk factors, which may persist into adulthood ${ }^{(3-4)}$.

A meta-analysis evaluated 55 studies on 5 continents, with a total of 122,053 adolescents, and found that the prevalence of high blood pressure was $11.2 \%$, with higher prevalence among boys ${ }^{(3)}$. The ERICA study found that $24 \%$ of adolescents had high blood pressure (BP), with $14.4 \%$ characterized as pre-hypertensive and $9.6 \%$ as hypertensive. The study also found that $17.1 \%$ were overweight and $8.4 \%$ were obese. The researchers found an association between obesity and hypertension ${ }^{(4)}$.

The health issue is even more concerning when adolescents have to work, taking on a double shift between work and school, reducing the time devoted to health care and exposing themselves to new health risk factors ${ }^{(5)}$.

Cardiovascular risk in adult workers is directly related to industrial societies. Possible explanations are stress and habits created or stimulated in the workplace. These include nonchemical sources, such as lack of physical activity and working under pressure, and chemical sources, such as active and passive smoking and alcohol consumption, which are common in business situations or social gatherings ${ }^{(6)}$. The mean systolic blood pressure (SBP) is about $4 \mathrm{mmHg}$ higher during working hours compared to other moments ${ }^{(7)}$.

Adolescent high school students who also work do not have specific qualifications, so they are assigned to less complex tasks, which are seen as simpler and easier than other services within a company. However, the activities performed by these individuals are not safer, easier or less unhealthy than the activities performed by adults ${ }^{(8)}$. The most common jobs for teenagers are: cashier, administrative assistant, packer, general assistant, cleaning assistant and messenger ${ }^{(5,8-9)}$.

Among adults, it is observed that individuals who are less qualified or occupy lower positions in a company are exposed to a greater number of cardiometabolic risk factors. The reason is that less qualified professionals have less control over the stress generated by work. Exposure to this situation compel individuals to seek immediate relief and pleasure, increasing alcohol and tobacco consumption and modifying eating habits ${ }^{(10-12)}$.

Adolescence is a phase of constant transformation, characterized by onset of maturity, increased independence and adoption of new habits, which may last for the rest of life ${ }^{(4,13)}$. Adolescent workers have characteristics that distinguish them from ordinary adolescents and from adult workers. This is because of their double schedule of school and work, changes in routine and new habits ${ }^{(8,14)}$. The influence of work on cardiovascular health is already known among adults; in the adolescent population, this issue is still not clear.

\section{OBJECTIVES}

To evaluate and compare the prevalence of cardiometabolic risk factors among high school adolescents with or without jobs, and to establish an association between risk factors and changes in lifestyle after starting to work.

\section{METHODS}

\section{Ethical aspects}

This research was approved by the Research Ethics Committee of the State University of Campinas - UNICAMP. It complies with the recommendations of Resolution No. 466/2012 on research involving human subjects.

\section{Design, period and study setting}

This is a cross-sectional quantitative study. Data collection occurred from October to November 2018 in three state schools in the city of Campinas. The instrument of Observational Studies in Epidemiology (STROBE) was used to guide the methodology.

\section{Population, inclusion and exclusion criteria}

The participants were 130 adolescents between 14 and 18 years old, workers and non-workers enrolled in school in the day or night period. Those classified as workers were adolescents who performed work activities, whether according to the Consolidation of Labor Laws (CLT), as interns or apprentices or in informal activities. Non-workers were the adolescents who did not perform any the activities mentioned above.

Inclusion criteria were: being between 14 and 18 years old and being enrolled in high school in a state public school. Exclusion criteria were: having an arm circumference that did not fit in the available cuffs; using antiarrhythmic drugs or having a diagnosis of arrhythmia; having a medical diagnosis of cognitive impairment; being enrolled in vocational courses; and being pregnant at the time of data collection.

\section{Study protocol}

In order to avoid bias, to ensure an effective approach and to arouse the interest of the adolescents, an approach strategy based on the an AIDA Model (Attention, Interest, Desire; Action) was developed ${ }^{(15)}$.

The participating classrooms were selected by draw. The groups were divided by school year, so classes from the 1st, 2nd and 3rd year of high school were chosen. If the number of students proposed for each school was not reached, a new draw was made to choose a new classroom from the school year that presented an inadequate number. Data was collected in the selected schools, on previously scheduled dates and times.

The variables studied to assess cardiometabolic risk behaviors and determinants were: gender, age, family income, blood pressure, Z-score, Brazilian Healthy Eating Index (BHEI), alcohol consumption, tobacco consumption, engagement in physical activity, physical condition and reported sleep quality. Behavior and habits variables were obtained based on a questionnaire elaborated by joining two instruments previously validated for this population ${ }^{(16-17)}$. The instrument created was submitted to the evaluation of five experts, resulting in a reformulated version. Subsequently, it was 
divided into three blocks: socio-demographic characterization, clinical characterization and life habits before and after starting to work. Alcohol and tobacco consumption and engagement in physical activity were considered as present if the adolescent reported having used the substances or engaged in physical activity, regardless of the number of uses/day or frequency in the week. To assess sleep quality, the analog scale from 0 (very bad) to 10 (very good) present in one of the original instruments was kept.

The 24 hours food recall (R24h) was used to assess the eating habits and food routine of this population. The instrument is based on a food record of the interviewee's previous day, recording the food consumed, its amount (in home measures), name of the meal, time and place. To apply the questionnaire, all researchers were properly trained by a professional with experience in R24h.

The data obtained in the food recall were entered in the software Nutrition Data System for Research (NDSR) version 2007 for Windows. At the end of registration, the content was exported to an Excel spreadsheet. To evaluate the dietary patterns of the studied population, the BHEl was used ${ }^{(18)}$.

The BHEl assesses food and nutrient intake based on dietary guidelines. With 12 components, it is divided in two major groups: adequacy group (Total fruit; Whole fruit; Total vegetables; Dark green and orange vegetables and legumes; Total grains; Whole grains; Milk and dairy products; Meat, eggs and beans; Oils) and moderation group (Saturated Fat; Sodium and SoFAAS - solid fats, alcohol, and added sugar) ${ }^{(18)}$.

Components receive a score ranging from zero (no consumption) to five, ten, or twenty points, according to the maximum score of the component. Intermediate values are adjusted according to the amount consumed. According to the scores of the components, the quality of the diet is classified into three groups: adequate, needs modification and inadequate. The BHEI was calculated using the program Windows Stata version 10.

The weight was obtained with a G-Tech Glass 10 digital body weight scale. Height was measured with a Wiso model E210 vertical stadiometer, measuring from 0 to $210 \mathrm{~cm}$. Both measurements were performed with the adolescent barefoot, with light clothing and no accessories. The participants were positioned in the Frankfurt plane, looking at a fixed point, with arms free and loose along the body, legs in parallel and feet forming a right angle with the legs. If the adolescent was not wearing appropriate clothing, nylon pants and a cotton t-shirt were provided, and the participant was asked to change in the school bathroom before performing the measurement. This procedure was performed by two researchers, who checked the value simultaneously, in order to ensure reliable data on heights.

Body Mass Index (BMI) was obtained by dividing weight in kilograms by the square of height in meters. The value obtained was transformed into a Z-score specific for adolescent and gender.

Blood pressure values were obtained by using a OMRON automatic arm device, model 705 IT, validated for adolescents, with three cuff sizes, chosen according to arm circumference ${ }^{(19)}$. The measurement procedures followed the guidelines of the VII Brazilian Guidelines on Hypertension ${ }^{(20)}$.

In order to avoid any kind of bias, a dice was thrown to decide which limb to measure first: even numbers indicated the right arm and odd numbers the left arm. All participants underwent 6 measurements, 3 on the left arm and 3 on the right arm. The first measurement of each arm was discarded and the mean SBP and diastolic blood pressure (DBP) of the last two were calculated.

The blood pressure classification followed the recommendations of the European Society of Hypertension ${ }^{(21)}$, which provides the following definition: for adolescents under 16 years of age, a percentile table was used, relating weight, height, age and gender. For adolescents who were 16 years old or older, regardless of gender, the same classification of adults was used.

\section{Analysis of results and statistics}

The sample size calculation for comparing groups of students was based on the methodology of sample size calculation for unpaired Student's t-test. This calculation used a significance level of $5 \%$, a test power of $80 \%$ and an effect size of 0.50 . The calculation resulted in a sample of 130 students. The data obtained were submitted to statistical analysis, comparing groups and periods, as well as association and correlation. The statistical programs SAS Version 9.4 and SPSS Version 22.0 were used.

\section{RESULTS}

The sample consisted of 130 adolescents from three schools. Of the total sample, $37.7 \%$ were male and $62.3 \%$ female. It was observed that most male adolescents already worked, while most females did not. It was also shown that adolescent work is associated with higher family income.

Among the participants, $7.7 \%$ had high blood pressure at the time of collection. High BP values were more prevalent in the group of adolescent workers, with $10.9 \%$, compared to $4.5 \%$ in the non-workers group. There was no relationship between work category and SBP and DBP values, nor was there any correlation between hours worked and SBP and DBP values.

The nutritional status assessed by the Z-score indicated that $28.3 \%$ of the sample were overweight. The evaluation by group showed that $27 \%$ of the adolescent workers and 29.7 of the nonworkers were overweight.

Table 1 - Socio-demographic characteristics of the sample, Campinas, São Paulo, Brazil, 2017

\begin{tabular}{|c|c|c|c|c|c|c|c|}
\hline \multirow{3}{*}{ Characteristics } & \multirow{2}{*}{\multicolumn{2}{|c|}{ Sample }} & \multicolumn{4}{|c|}{ Employment Bond } & \multirow{3}{*}{$p$ value } \\
\hline & & & & & & & \\
\hline & $\mathbf{n}$ & $\%$ & $\mathbf{n}$ & $\%$ & $\mathbf{n}$ & $\%$ & \\
\hline \multicolumn{8}{|l|}{ Gender } \\
\hline Male & 49 & 37.70 & 22 & 33.30 & 27 & 42.20 & $0.2976^{*}$ \\
\hline Female & 81 & 62.30 & 44 & 66.70 & 37 & 57.80 & \\
\hline \multicolumn{8}{|l|}{ Age } \\
\hline 14-15 & 9 & 6.90 & 9 & 13.60 & 0 & 0.00 & $0.0029 * *$ \\
\hline $16-18$ & 121 & 93.10 & 57 & 86.40 & 64 & 100.00 & \\
\hline \multicolumn{8}{|c|}{$\begin{array}{l}\text { No. of people in the } \\
\text { household }\end{array}$} \\
\hline $01-04$ & 85 & 78.70 & 36 & 80.00 & 49 & 77.80 & $0.7809^{*}$ \\
\hline 5 or more & 23 & 21.30 & 9 & 20.00 & 14 & 22.20 & \\
\hline \multicolumn{8}{|c|}{$\begin{array}{l}\text { Family income } \\
\text { (in minimum wages)*** }\end{array}$} \\
\hline Até 1 & 2 & 1.70 & 1 & 1.90 & 1 & 1.60 & $0.0022 *$ \\
\hline $2-3$ & 63 & 53.80 & 39 & 72.20 & 24 & 38.10 & \\
\hline $4-5$ & 25 & 21.40 & 8 & 14.80 & 17 & 27.00 & \\
\hline$>5$ & 27 & 23.10 & 6 & 11.10 & 21 & 33.30 & \\
\hline
\end{tabular}

Note: * $p$ value obtained by the Pearson's Chi-square Test; ${ }^{* *} p$ value obtained by the Fisher's Exac Test; ${ }^{* * *}$ Minimum wage value in the month of data collection: $R \$ 937.00$. 
Table 2 - Categories of blood pressure, Z-score, BHEl, engagement in physical activity, alcohol and tobacco consumption in the whole sample and in relation to employment bond, Campinas, São Paulo, Brazil, 2017

\begin{tabular}{|c|c|c|c|c|c|c|c|}
\hline \multirow{3}{*}{ Variable } & \multirow{2}{*}{\multicolumn{2}{|c|}{$\begin{array}{c}\text { Total } \\
\text { sample }\end{array}$}} & \multicolumn{4}{|c|}{ Employment Bond } & \multirow{3}{*}{$p$ value } \\
\hline & & & \multicolumn{2}{|c|}{ No } & \multicolumn{2}{|c|}{ Yes } & \\
\hline & & $\%$ & $\mathbf{n}$ & $\%$ & $\mathbf{n}$ & $\%$ & \\
\hline Blood pressure & & & & & & & $0.2030^{* *}$ \\
\hline Normotensive & 120 & 92.30 & 63 & 95.50 & 57 & 74.75 & \\
\hline Elevated BP & 10 & 07.70 & 03 & 4.50 & 07 & 10.90 & \\
\hline Z-Score & & & & & & & $0.7354^{*}$ \\
\hline Normal & 91 & 71.70 & 45 & 70.30 & 46 & 73.00 & \\
\hline Overweight & 36 & 28.30 & 19 & 29.70 & 17 & 27.00 & \\
\hline BHEl *** & & & & & & & $0.5817^{*}$ \\
\hline Needs modification & 63 & 61.20 & 35 & 55.60 & 28 & 44.80 & \\
\hline Inadequate & 40 & 38.80 & 20 & 36.40 & 20 & 41.70 & \\
\hline $\begin{array}{l}\text { Engagement in physical } \\
\text { activity }\end{array}$ & & & & & & & $0.4217^{*}$ \\
\hline Yes & 63 & 48.80 & 35 & 52.00 & 28 & 45.20 & \\
\hline No & 66 & 51.20 & 32 & 47.80 & 34 & 54.80 & \\
\hline Alcohol consumption & & & & & & & $0.0085^{*}$ \\
\hline Yes & 58 & 44.60 & 22 & 43.80 & 36 & 56.30 & \\
\hline No & 72 & 55.40 & 44 & 66.70 & 28 & 43.80 & \\
\hline Tobacco consumption & & & & & & & $0.1756^{*}$ \\
\hline Yes & 12 & 09.30 & 04 & 06 & 08 & 12.90 & \\
\hline No & 117 & 90.70 & 63 & 94 & 54 & 87.10 & \\
\hline \multicolumn{8}{|c|}{$\begin{array}{l}\text { Note: }{ }^{*} p \text { value obtained by the Chi-square test; }{ }^{*} p \text { value obtained by the Fisher's test; }{ }^{* * *} \text { BHEl } \\
\text { Brazilian Healthy Eating Index. }\end{array}$} \\
\hline \multicolumn{8}{|c|}{$\begin{array}{l}\text { Table } 3 \text { - Frequency of engagement in physical activity and alcohol and } \\
\text { tobacco consumption among adolescent workers before and after the } \\
\text { beginning of their work activities. } N=64 \text {, Campinas, São Paulo, Brazil, } 2017\end{array}$} \\
\hline & & Wo & rk ac & tivity & & & \\
\hline Habit & & efore & & & & & $p$ value \\
\hline Physical activity & 43 & 67.7 & & 28 & 43.7 & & 0.0053 \\
\hline Tobacco consumption & 06 & 9.3 & & 09 & 14.0 & & 0.7630 \\
\hline Alcohol consumption & 28 & 43.7 & & 36 & 56.2 & & 0.0593 \\
\hline
\end{tabular}

Note: ${ }^{*} p$ value obtained by the McNemar test.

Table 4 - Score of reported quality sleep among adolescent workers before and after starting to work, Campinas, São Paulo, Brazil, 2017

\begin{tabular}{lccccc}
\hline Variable & Time & $\mathbf{n}$ & Sleep Score & Standard Deviation & $\boldsymbol{p}$ value \\
\hline Sleep score & 0 & 64 & 7.34 & 2.32 & \\
& 1 & 64 & 5.94 & $\mathbf{0 . 0 0 1 1 ^ { * }}$ \\
\hline
\end{tabular}

Note: *p value obtained through the paired Student's t-test.

Consumption of sugar sweetened beverages was present in both groups: $93.1 \%$ of adolescents reported consumption of soft drinks and $82 \%$ reported consumption of processed juices. The comparison between groups showed no significant differences.

There was an association between alcohol consumption and work. There was no association between work and tobacco use or engagement in physical activity.

The mean overall BHEl score did not show adequate values when analyzed globally or by groups. Among the group of workers, it was 52.19 points and among non-workers, 54.96 points. The analysis of the behavior of the group of workers before and after starting to work, showed a significant reduction in engagement in physical activity.

When asked where they eat their meals, $28.1 \%$ adolescent workers reported taking food from home and $21.9 \%$ reported eating in the cafeteria where they work. The least mentioned places were restaurants (4.7\%) and home (9.4\%).

It was also revealed that work reduced the reported quality of sleep. When asked to evaluate their sleep before and after starting to work on a numerical scale from 0 to 10 points, there was a decrease of 1.4 points, making the difference between the two periods statistically significant.

\section{DISCUSSION}

The results presented here showed there are differences in the lifestyle and behavior of the sample, which can interfere in the health-disease process of the adolescent. Working was a reason for socio-economic differences and health risks.

The prevalence of high BP in this sample was $7.7 \%$. When evaluating differences between groups, a difference of $6.4 \%$ was found. When classifying altered blood pressure, it is observed that only the group of adolescent workers has BP values equivalent to arterial hypertension, which does not mean that they are hypertensive. This classification represents $2.3 \%$ of the sample. National studies evaluating high BP in adolescents found prevalence rates between $2.6 \%$ and $24 \%$, showing that values may vary according to region, age group, method and device used to measure $\mathrm{BP}^{(4,22-}$ ${ }^{24)}$. Large national studies have also found that blood pressure is higher among the population over 16 years old ${ }^{(4,22)}$. Data presented here shows that from this age on the number of workers increases, which may influence BP.

The fact that work influences alcohol consumption can be clearly seen when analyzing consumption before and after beginning of work: although not statistically significant, the number of adolescents who consumed alcohol after starting to work almost doubled. National and international research have also found an association between alcohol consumption and work in adolescents lives, and have warned that, in addition to health risks, there are also social risks ${ }^{(25-26)}$.

In this research, $48.8 \%$ of the total sample reported engaging in regular physical activity, a value similar to that presented in a document from the Brazilian Institute of Geography and Statistics (IBGE) ${ }^{(27)}$.

The sleep scores reported by adolescent workers demonstrated that work interferes with the perception of sleep of this population. The difference between the scores chosen before and after starting work was significant. Adolescents often verbalized that they felt more tired and had difficulty concentrating. Other research has shown similar results ${ }^{(5,14)}$. A study conducted in Cleveland with participants aged 13 to 16 years with no severe illness evaluated sleep quality and its association with blood pressure values. The authors found an association between poor sleep quality and pre-hypertension in healthy adolescents ${ }^{(28)}$.

Among the total adolescents interviewed, 93.1\% and $82.2 \%$ reported consuming soft drinks and processed juices, respectively, at least once a week, with no statistical difference between the groups. The National School Health Survey (PeNSE) showed a significant increase in the consumption of these beverages in this age group $^{(29)}$. A study carried out in Rio de Janeiro with public school students between 12 and 18 years old analyzed two cross-sectional studies, with identical methodological design and a gap of five years between them. The researchers found a reduction of milk 
consumption during weekdays and weekends, and a significant increase in the consumption of sugar-sweetened beverages. Soft drinks were more prominent in the daily calorie intake of this population, and in the first moment they were more consumed on weekends. Another study found high consumption of soft drinks, regardless of the day of the week ${ }^{(30)}$. However, increased consumption of sugar-sweetened beverages alone, regardless of age and social status, cannot be considered as a condition for BMI increase in adolescents, as there is no consensus on the subject ${ }^{(31)}$.

The Z-score had similar results to those found in several national and international surveys $s^{(4,13)}$.

The National Health and Nutrition Examination Survey (NHANES) found that the prevalence of obesity among U.S. youth aged 12-19 years was $20.6 \%$, while extreme obesity affected $9.1 \%$ of this population. Analyzing a 25-year period, the researchers observed a significant increase in obesity and extreme obesity trends in this age group ${ }^{(13)}$.

The ERICA study evaluated the BMI of Brazilian adolescents. The researchers chose to use the Z-score to evaluate this age group. The national rate of overweight among adolescents between 15 and 17 years old was $22.9 \%$. The Southeast region had rates higher than national, with $24.8 \%$ of overweight. The researchers found an association between obesity and hypertension ${ }^{(4)}$. In the present study, the rate of overweight was $28.6 \%$, above the value found in the ERICA study ${ }^{(4)}$. When comparing the groups, work did not affect the body mass index of the adolescents.

The mean BHEl of the participants of this study was 53.66. National studies have evaluated the diet quality of Brazilian adolescents in various regions of the country ${ }^{(32-34)}$. In the Southeast region, the means found were very close to those reported here, ranging from 58.3 to $63.1^{(32-33,35)}$. In the city of Campinas, researchers evaluated $\mathrm{BHEl}$ in adolescents aged 12 to 17 years ${ }^{(33)}$ and found a mean value of 59.7, which is very close to the value found in the present study.

Adolescent workers had a mean BHEl of 52.19 points, while non-workers had a mean of 54.96 points, which did not represent a significant difference. The similarity of the $\mathrm{BHEl}$ score and its components between groups may be justified by where the adolescent workers ate their meals: $37.5 \%$ ate homemade food and $21.9 \%$ ate in company cafeterias. Thus, even though adolescent workers may buy unhealthy food with their income, the most important meals are prepared by parents or guardians or in the nutrition service of the company where they work. On the other hand, meals of non-workers were eaten at home and prepared by parents. This can explain the similarity of the BHEI scores of both groups.

Even with meals prepared by the nutrition services of the companies, there is no guarantee of the quality of the meals served to employees, which may be related to the fact that no adolescent worker presented an adequate $\operatorname{diet}^{(36)}$.

\section{Limitations of the study}

It is important to point out that some data may have memory bias, as they were collected only in one moment, requiring adolescents to remember their habits before starting to work.

\section{Contributions to the area of health}

This study made it possible to understand the influence of work on the health of adolescents and to know the cardiometabolic risk factors to which this population is exposed. In addition, it may assist in public policy strategies.

\section{CONCLUSIONS}

Work is a condition that distinguishes the adolescent who only studies from the adolescent who takes on a double shift (work and study). This situation leads to changes in routine and greater exposure to certain risk factors. In the sample studied, the prevalence of high BP values was 7.7\% (10.9\% among workers and $4.5 \%$ among non-workers). Employment bonds increased alcohol consumption and decreased reported quality of sleep and engagement in physical activity. There was also reduction in BHEl score; however, this was not significant. Obesity and tobacco consumption did not have any differences between the groups.

Regardless of work, poor diets, lack of physical activity and obesity show that there is a problem in this age group. These results show the influence of contemporary society and the obesogenic environment to which these adolescents are exposed.

Finally, the presence of cardiometabolic risk factors associated to work justifies further research in this age group.

\section{ACKNOWLEDGMENT}

The authors acknowledge to Karyne Uyeno and Karina Izzo their contribution to the research.

\section{REFERENCES}

1. Dawber TR, Kannel WB, Revotskie N, Stokes J, Kagan A, Gordon T. Some factors as-sociated with the development of coronary heart disease: six years' follow-up experi-ence in the Framingham study. Am J Public Health. 1959;49:1349-1356. doi: 10.2105/AJPH.49.10.1349

2. Stamler J, Stamler R, Neaton JD, Wentworth D, Garside D, Dyer AR, et al. Low Risk-Factor Profile and Long-term Cardiovascular and Noncardiovascular. J Am Med Assoc. 1999;282(21):2012-8. doi:10.1001/jama.282.21.2012

3. Moraes ACF, Lacerda MB, Moreno LA, Horta BL, Carvalho HB. Prevalence of High Blood Pressure in 122,053 Adolescents. Medicine (Baltimore). 2014;93(27):e232. doi: 10.1097/MD.0000000000000232

4. Bloch KV, Klein CH, Szklo M, Kuschnir MCC, Abreu GA, Barufaldi LA, et al. ERI-CA: Prevalences of hypertension and obesity in Brazilian adolescents. Rev Saude Pub-lica. 2016;50(supl 1):9s. doi: 10.1590/S01518-8787.2016050006685 
5. Fischer FM, Oliveira DC, Nagai R, Teixeira LR, Lombardi Jr M, Latorre MRDO, et al. Job control, job demands, social support at work and health among adolescent work-ers. Rev Saude Publica. 2005;39(2):245-53. doi: /S0034-89102005000200016

6. Souza NRM, Souza e Silva NA. Trabalho e hipertensão arterial. A responsabilidade so-cial das empresas: problemas, oportunidades e possíveis estratégias de intervenção. Rev SOCERJ. 2003;16(1):60 - 4

7. Landsbergis PA, Diez-Roux AV, Fujishiro K, Baron S, Kaufman JD, Meyer JD, et al. Job strain, occupational category, systolic blood pressure, and hypertension prevalence the multi - ethnic study of atherosclerosis. J Occup Environ Med. 2015;57(11):1178-84. doi: 10.1097/ JOM.0000000000000533

8. Oliveira BRG, Robazzi MLCC. O trabalho na vida dos adolescentes: alguns fatores de-terminantes para o trabalho precoce. Rev Latino-Am Enfermagem. 2001;9(3):83-9. doi: 10.1590/S0104-11692001000300013

9. Pimenta AA, Freitas FCT, Marziale MHP, Robazzi MLCC. Repercussões do trabalho na saúde dos adolescentes trabalhadores. Acta Paul Enferm 2011;24(5):701-6. doi: 10.1590/S0103- 21002011000500017

10. Wiernik E, Pannier B, Czernichow S, Nabi H, Hanon O, Simon T, et al. Occupational status moderates the association between current perceived stress and high blood pres-sure: evidence from the IPC cohort study. Hypertens. 2013;61(3):571-7. doi: 10.1161/HYPERTENSIONAHA.111.00302

11. Rocco PTP, Bensenor IM, Griep RH, Moreno AB, Alencar AP, Lotufo PA, et al. Job Strain and Cardiovascular Health Score (from the Brazilian Longitudinal Study of Adult Health [ELSA - Brasil] Baseline). Am J Cardiol. 2017;120(2):207-12. doi: 10.1016/j.amjcard.2017.04.008

12. Vinholes DB, Bassanesi SL, Chaves Jr HC, Machado CA, Melo IMF, Fuchs FD, et al. Association of workplace and population characteristics with prevalence of hyperten-sion among Brazilian industry workers: a multilevel analysis. BMJ Open. 2017;7(8):e015755. doi: 10.1136/ bmjopen-2016-015755

13. Ogden CL, Carroll MD, Lawman HG, Fryar CD, Kruszon-Moran D, Kit BK, et al. Trends in obesity prevalence among children and adolescents in the United States, 1988-1994 through 2013 -2014. J Am Med Assoc. 2016;315(21):2292-9. doi:10.1001/jama.2016.6361

14. Fischer FM, Wey D, Valente D, Luz AAD, Pinheiro F, Fonseca BC, et al. Sleep patterns and sleepiness among young students: A longitudinal study before and after admission as trainees and apprentices. Chronobiol Int. 2015;32(4):478-485. doi: 10.3109/07420528.2014.993765

15. Rawal P. AIDA Marketing Communication Model: Stimulating a purchase decision in the minds of the consumers through a linear progression of steps. Int J Multidiscip Res Soc Manag Sci. 2013;1(1):37-44

16. Vasconcellos MTL, Silva PLN, Szklo M, Kuschnir MCC, Klein CH, Abreu GA, et al. Sampling design for the Study of Cardiovascular Risks in Adolescents (ERICA). Cad Saude Publica. 2015;31(5):921-30. doi: 10.1590/0102-311X00043214

17. Luz AA, Silva MCMV, Turte SL, Lopes MO, Fischer FM. Effects of working full-time and studying in the evening hours among young apprentices and trainees. Hum Factors. 2012;54(6):952-63. doi: 10.1177/0018720812463146

18. Previdelli AN, Andrade SC, Pires MM, Ferreira SRG, Fisberg RM, Marchioni DM. Índi-ce de Qualidade da Dieta Revisado para população brasileira. Rev Saude Publica. 2011;45(4):794-8. doi: 10.1590/S0034-89102011005000035

19. Stergiou GS, Yiannes NG, Rarra VC. Validation of the Omron 705 IT oscillometric de-vice for home blood pressure measurement in children and adolescents: the Arsakion School Study. Blood Press Monit. 2006;11(4):229-34. doi: 10.1097/01.mbp.0000209074.38331.1

20. Malachias MVB, Souza WKSB, Plavnik FL, Rodrigues CIS, Brandão AA, Neves MFT, et al. 7a Diretriz Brasileira de Hipertensão Arterial. Arq Bras Cardiol 2016;107(3Supl.3):1-83. doi: 10.5935/abc.20160153

21. Lurbe E, Agabiti-Rosei E, Kennedy Cruickshank J, Dominiczak A, Erdine S, Hirth A, et al. European Society of Hypertension guidelines for the management of high blood pressure in children and adolescents. J Hypertens. 2016;34:1887-920. doi: 10.1097/HJH.00000000000001039

22. Almeida MMS, Guimarães RA, Jardim PCBV, Sousa ALL, Souza MM. Association be-tween arterial hypertension and nutritional status in adolescents from Goiânia, Goiás, Brasil. PLoS One. 2017;12(12):1-17. doi: 10.1371/journal.pone.0188782

23. Gonçalves VSS, Galvão TF, Andrade KRC, Dutra ES, Bertolin MNT, Carvalho KMB, et al. Prevalence of hypertension among adolescents: Systematic review and meta-analysis. Rev Saude Publica. 2016;50:27. doi: 10.1590/S1518-8787.2016050006236

24. Suglia SF, Koenen KC, Boynton-Jarrett R, Chan PS, Clark CJ, Danese A, et al. Child-hood and adolescent adversity and cardiometabolic outcomes: circulation. 2017;137(5):e15-e28. doi: 10.1161/CIR.0000000000000536

25. Liu XC, Keyes KM, Li G. Work stress and alcohol consumption among adolescents: moderation by family and peer influences. BMC Public Health. 2014;14(1):1 -7. doi: 10.1186/1471-2458-14-1303

26. Barbosa Filho VC, Campos W, Lopes AS. Prevalence of alcohol and tobacco use among Brazilian adolescents : a systematic review. Rev Saúde Pública. 2012;46(5):901 -17. doi: 10.1590/S0034-89102012000500018

27. Instituto Brasileiro de Geografia e Estatística (IBGE). Práticas de Esporte e Atividade Física em 2015. Rio de Janeiro: IBGE. 2017, 81p.

28. Javaheri S, Storfer -Isser A, Rosen CL, Redline S. Sleep quality and elevated blood pressure in adolescents. Circulat. 2008;118(10):1034-40. doi: 10.1161/CIRCULATIONAHA.108.766410

29. Instituto Brasileiro de Geografia e Estatística (IBGE). Pesquisa Nacional de Saúde do Escolar. Rio de Janeiro: IBGE; 2015.

30. Monteiro LS, Vasconcelos TMD, Veiga GVD, Pereira RA. Modificações no consumo de bebidas de adolescentes de escolas públicas na primeira década do século XXI. Rev Bras Epidemiol. 2016;19:348-361. doi: 10.1590/1980-5497201600020012

31. Keller A, Bucher Della Torre S. Sugar -sweetened beverages and obesity among chil-dren and adolescents: a review of systematic literature reviews. Childhood Obesity. 2015;11(4):338-46. doi: 10.1089/chi.2014.0117 
32. Monteiro LS, Rodrigues PRM, Veiga GV, Marchioni DML, Pereira RA. Diet quality among adolescents has deteriorated: a panel study in Niterói, Rio de Janeiro State, Bra-zil, 2003-2008. Cad Saude Publica. 2016;32(12):1 -10. doi: 10.1590/0102 -311x00124715

33. Assumpção D, Barros MBA, Fisberg RM, Carandina L, Goldbaum M, Cesar CLG. Qualidade da dieta de adolescentes: estudo de base populacional em Campinas, SP. Rev Bras Epidemiol. 2012;15(3):605-16. doi: 10.1590/S1415-790X2012000300014

34. Wendpap LL, Ferreira MG, Rodrigues PRM, Pereira RA, Loureiro AS, Gonçalves-Silva RMV. Qualidade da dieta de adolescentes e fatores associados. Cad Saude Publica. 2014;30(1):97-106. doi: 10.1590/0102-311X0008241

35. Godoy FC, Andrade SC, Morimoto JM, Carandina L, Goldbaum M, Barros MBA, et al, Fisberg RM. Healthy eating index of adolescents living in Butanta's District, Sao Paulo, Brazil. Rev Nutr. 2006;19:663-71. doi: 10.1590/S1415-52732006000600003

36. Pereira JP, Bello PD, Locatelli NT, Souza Pinto AM, Bandoni DH. Qualidade das refei-ções oferecidas por empresas cadastradas pelo Programa de Alimentação do Trabalha-dor na cidade de Santos-SP. Mundo Saúde.2014;38(3):325-33. doi: 10.15343/0104-7809.20143803325333 